\title{
Malignant Cell Count
}

National Cancer Institute

\section{Source}

National Cancer Institute. Malignant Cell Count. NCI Thesaurus. Code C74660.

The determination of the number of malignant cells present in a sample. 